\title{
Worldwide differences in COVID-19-related mortality
}

\author{
Diferenças nas taxas de mortalidade por COVID-19 \\ ao redor do mundo
}

Pedro Curi Hallal (https://orcid.org/0000-0003-1470-6461) ${ }^{1}$

${ }^{1}$ Programa de PósGraduação em Epidemiologia, Universidade Federal de Pelotas. R. Marechal Deodoro 1160, Centro. 96020-220 Pelotas RS Brasil.prchallal@gmail.com

\begin{abstract}
Mortality statistics due to COVID-19 worldwide are compared, by adjusting for the size of the population and the stage of the pandemic. Data from the European Centre for Disease Control and Prevention, and Our World in Data websites were used. Analyses are based on number of deaths per one million inhabitants. In order to account for the stage of the pandemic, the baseline date was defined as the day in which the $10^{\text {th }}$ death was reported. The analyses included 78 countries and territories which reported 10 or more deaths by April 9. On day 10, India had 0.06 deaths per million, Belgium had 30.46 and San Marino 618.78. On day 20, India had 0.27 deaths per million, China had 0.71 and Spain 139.62. On day 30, four Asian countries had the lowest mortality figures, whereas eight European countries had the highest ones. In Italy and Spain, mortality on day 40 was greater than 250 per million, whereas in China and South Korea, mortality was below 4 per million. Mortality on day 10 was moderately correlated with life expectancy, but not with population density. Asian countries presented much lower mortality figures as compared to European ones. Life expectancy was found to be correlated with mortality.
\end{abstract}

Key words COVID-19, Epidemiology, Mortality
Resumo Neste artigo, são comparadas as estatísticas de mortalidade por COVID-19 no mundo, ajustando-se para o tamanho da população $e$ para o estágio da pandemia em cada país. Foram utilizados dados dos websites do Centro para o Controle e Prevenção de Doenças da Europa e do Our World in Data. As análises são baseadas no número de mortes por um milhão de habitantes. Para levar em consideração o estágio da pandemia, definiu-se como linha de base a data da décima morte em cada país. As análises incluíram 78 países e territórios com 10 ou mais mortes relatadas até o dia 09 de abril. No dia 10, a Índia tinha 0,06 mortes por um milhão, a Bélgica 30,46 e San Marino 618,78. No dia 20, a Índia tinha 0,27 mortes por um milhão, a China 0,71 e a Espanha 139,62. No dia 30, quatro países da Ásia tinham as menores taxas de mortalidade, enquanto que oito países europeus tinham as maiores. Na Itália e na Espanha, a mortalidade no dia 40 era maior do que 250 por um milhão, enquanto que na China e na Coréia do Sul era abaixo de 4 por um milhão. A mortalidade no dia 10 correlacionou-se moderadamente com a expectativa de vida, mas não mostrou correlação com a densidade populacional. Os países asiáticos apresentaram taxas de mortalidade muito menores do que aquelas observadas nos europeus. A expectativa de vida correlacionou-se com a mortalidade.

Palavras-chave COVID-19, Epidemiologia, Mortalidade 


\section{Introduction}

COVID-19, the disease produced by the SARSCoV-2 virus, was first reported in China in late 2019. After being declared by the World Health Organization as an international health emergency on January 30, 2020, COVID-19 was declared pandemic on March 11, 20201. Less than six months after the first case, over 150,000 people died around the world (as of April 18, 2020). In a single day (April 16, 2020), almost 5,000 people lost their lives in the United States due to COVID-192.

Official statistics on the number of COVID-19 cases are severely biased ${ }^{3}$. First, testing policies vary around the globe, with most countries testing only symptomatic patients, particularly the ones with more severe symptoms. Second, the availability of tests is not compatible with the demand. Consequently, looking at official statistics on confirmed cases is a perfect analogy to an iceberg. The part of it that our eyes can see is just a small fraction of the real size of the iceberg. A recent report using data from a population sample of 4,189 individuals in South Brazil estimated that the estimated number of cases is 7-8 times greater than the number of notified cases. In Santa Clara, US, the estimated number of cases was 50-85 times greater than the number of registered cases $^{3}$. In summary, dealing with the number of confirmed cases is misleading, due to the lack of a proper denominator ${ }^{5}$.

Official statistics on deaths represent a much more reliable platform to understand the dynamics of COVID-19. In this article, we compare mortality statistics due to COVID-19 worldwide, by adjusting for the size of the population and the stage of the pandemic in each country. We also present the correlation between mortality and (a) life expectancy; (b) population density. By using these methods, we disentangle misinterpretation and fake news from scientific evidence.

\section{Methods}

Data used in this analysis are freely available at the European Centre for Disease Control and Prevention, and the Our World in Data websites. All analyses are based on number of deaths per one million inhabitants. In order to take into account the stage of the pandemic, the baseline date for each country was set as the day in which the $10^{\text {th }}$ death was reported in that particular country. Mortality statistics are presented for days 10 , 20,30 and 40 since the $10^{\text {th }}$ death.
We excluded from our analysis the 125 countries and territories that have reported less than 10 deaths by April 18,2020, as well as those in which the $10^{\text {th }}$ death was reported after April 8, 2020. Excluded countries and territories were: Angola, Anguilla, Antigua and Barbuda, Armenia, Aruba, Azerbaijan, Bahamas, Bahrein, Barbados, Belize, Benin, Bermuda, Bhutan, Boner Saint Eustatius and Saba, Botswana, British Virgin Island, Brunei Darussalam, Burundi, Cambodia, Cameroon, Cape Verde, Cayman Islands, Central African Republic, Chad, Congo, Costa Rica, Cote D'Ivoire, Curacao, Djibouti, Dominica, El Salvador, Equatorial Guinea, Eritrea, Eswatini, Ethiopia, Falkland Islands, Faroe Islands, Fiji, French Polynesia, Gabon, Gambia, Georgia, Ghana, Gibraltar, Greenland, Grenada, Guam, Guatemala, Guernsey, Guinea, Guinea Bissau, Guyana, Haiti, Holy Sea, Iceland, Isle of Man, Jamaica, Jersey, Jordan, Kazakhstan, Kenya, Kosovo, Kuwait, Kyrgyzstan, Laos, Latvia, Liberia, Libya, Liechtenstein, Madagascar, Malawi, Maldives, Mali, Malta, Mauritania, Mauritius, Monaco, Mongolia, Montenegro, Montserrat, Mozambique, Myanmar, Namibia, Nepal, New Caledonia, New Zealand, Nicaragua, Nigeria, Northern Mariana Islands, Oman, Palestine, Papua New Guinea, Paraguay, Qatar, Rwanda, Saint Kitts and Nevis, Saint Lucia, Saint Vincent and the Grenadines, Sao Tome and Principe, Senegal, Seychelles, Sierra Leone, Singapore, Saint Maarten, Slovakia, Somalia, South Sudan, Sri Lanka, Sudan, Suriname, Syria, Taiwan, Timor Leste, Togo, Trinidad and Tobago, Turks and Caicos, Uganda, United Republic of Tanzania, United States Virgin Islands, Uruguay, Uzbekistan, Venezuela, Vietnam, Yemen, Zambia, Zimbabwe.

We also obtained freely available statistics from the United Nations on life expectancy, and from the World Bank on population density. Life expectancy data were not available for Puerto Rico and San Marino, and therefore, we obtained them from different sources (Puerto Rico: Statista.com; San Marino: Indexmundi.com). We plotted mortality on day 10 since the $10^{\text {th }}$ death in each country with (a) life expectancy; and (b) population density, as well as calculated Spearman's correlation coefficients (rho).

\section{Results}

Table 1 lists the 78 countries and territories included in the analysis by alphabetical order. The mortality variation was remarkably high: on day 
Table 1. Mortality per one million inhabitants on days 10, 20, 30 and 40 since the $10^{\text {th }}$ death (baseline) in each country.

\begin{tabular}{|c|c|c|c|c|c|}
\hline Country & Baseline & Day 10 & Day 20 & Day 30 & Day 40 \\
\hline Afghanistan & Apr 8 & 0.77 & & & \\
\hline Albania & Mar 29 & 7.64 & 9.03 & & \\
\hline Algeria & Mar 21 & 0.80 & 5.36 & & \\
\hline Andorra & Apr 1 & 336.50 & & & \\
\hline Argentina & Mar 27 & 1.02 & 2.41 & & \\
\hline Australia & Mar 26 & 1.33 & 2.39 & & \\
\hline Austria & Mar 23 & 16.21 & 37.42 & & \\
\hline Bangladesh & Apr 7 & 0.36 & & & \\
\hline Belarus & Apr 7 & 4.23 & & & \\
\hline Belgium & Mar 19 & 30.46 & 175.59 & 445.48 & \\
\hline Bolivia & Apr 4 & 2.40 & & & \\
\hline Bosnia and Herzegovina & Apr 1 & 11.28 & & & \\
\hline Brazil & Mar 23 & 1.13 & 5.29 & & \\
\hline Bulgaria & Apr 2 & 4.03 & & & \\
\hline Burkina Faso & Mar 31 & 1.15 & & & \\
\hline Canada & Mar 20 & 1.62 & 11.53 & & \\
\hline Chile & Apr 1 & 3.40 & & & \\
\hline China & $\operatorname{Jan} 22$ & 0.18 & 0.71 & 1.55 & 2.02 \\
\hline Colombia & Mar 30 & 1.08 & & & \\
\hline Croatia & Apr 5 & 7.55 & & & \\
\hline Cuba & Apr 8 & 2.74 & & & \\
\hline Cyprus & Apr 4 & 14.08 & & & \\
\hline Czech Republic & Mar 29 & 8.22 & 16.15 & & \\
\hline Democratic Republic of Congo & Apr 2 & 0.22 & & & \\
\hline Denmark & Mar 22 & 15.54 & 42.64 & & \\
\hline Dominican Republic & Mar 26 & 7.10 & 16.87 & & \\
\hline Ecuador & Mar 23 & 6.80 & 17.85 & & \\
\hline Egypt & Mar 23 & 0.45 & 1.43 & & \\
\hline Estonia & Apr 3 & 18.85 & & & \\
\hline Finland & Mar 30 & 7.22 & & & \\
\hline France & Mar 8 & 2.68 & 30.56 & 136.52 & 274.54 \\
\hline Germany & Mar 16 & 2.36 & 16.02 & 38.84 & \\
\hline Greece & Mar 22 & 4.70 & 8.63 & & \\
\hline Honduras & Apr 1 & 2.42 & & & \\
\hline Hungary & Mar 25 & 3.31 & 12.63 & & \\
\hline India & Mar 26 & 0.06 & 0.27 & & \\
\hline Indonesia & Mar 20 & 0.42 & 0.88 & & \\
\hline Iran & Feb 25 & 1.27 & 8.62 & 24.73 & 41.10 \\
\hline Iraq & Mar 18 & 0.99 & 1.59 & 1.99 & \\
\hline Ireland & Mar 27 & 32.00 & 89.92 & & \\
\hline Israel & Mar 28 & 6.59 & 16.41 & & \\
\hline Italy & Feb 26 & 3.26 & 35.69 & 135.04 & 262.79 \\
\hline Japan & Mar 11 & 0.28 & 0.44 & 0.67 & \\
\hline Lebanon & Mar 30 & 2.78 & & & \\
\hline Lithuania & Apr 6 & 10.65 & & & \\
\hline Luxembourg & Mar 28 & 65.5 & 110.23 & & \\
\hline Malaysia & Mar 23 & 1.39 & 2.26 & & \\
\hline Mexico & Mar 28 & 0.97 & 3.77 & & \\
\hline Moldova & Apr 5 & 9.92 & & & \\
\hline Morocco & Mar 27 & 1.90 & 3.44 & & \\
\hline
\end{tabular}


Table 1. Mortality per one million inhabitants on days 10, 20, 30 and 40 since the $10^{\text {th }}$ death (baseline) in each country.

\begin{tabular}{|c|c|c|c|c|c|}
\hline Country & Baseline & Day 10 & Day 20 & Day 30 & Day 40 \\
\hline Netherlands & Mar 15 & 16.11 & 86.78 & 164.75 & \\
\hline North Macedonia & Apr 2 & 16.32 & & & \\
\hline Norway & Mar 25 & 8.12 & 21.03 & & \\
\hline Pakistan & Mar 29 & 0.26 & 0.65 & & \\
\hline Panama & Mar 28 & 12.75 & 25.26 & & \\
\hline Peru & Mar 28 & 2.79 & 8.31 & & \\
\hline Philippines & Mar 16 & 0.35 & 1.31 & 3.06 & \\
\hline Poland & Mar 25 & 1.88 & 6.47 & & \\
\hline Portugal & Mar 22 & 15.69 & 42.66 & & \\
\hline Puerto Rico & Apr 2 & 14.68 & & & \\
\hline Romania & Mar 25 & 6.91 & 16.53 & & \\
\hline Russia & Mar 31 & 0.52 & & & \\
\hline San Marino & Mar 18 & 618.78 & 942.90 & 1119.69 & \\
\hline Saudi Arabia & Apr 1 & 1.35 & & & \\
\hline Serbia & Mar 29 & 8.96 & 16.17 & & \\
\hline Slovenia & Mar 30 & 19.24 & & & \\
\hline South Africa & Apr 6 & 0.57 & & & \\
\hline South Korea & Feb 26 & 0.86 & 1.58 & 2.71 & 3.63 \\
\hline Spain & Mar 10 & 16.40 & 139.62 & 311.31 & \\
\hline Sweden & Mar 19 & 10.10 & 58.52 & 138.62 & \\
\hline Switzerland & Mar 15 & 9.94 & 55.92 & 99.14 & \\
\hline Thailand & Mar 31 & 0.47 & & & \\
\hline Tunisia & Apr 2 & 2.37 & & & \\
\hline Turkey & Mar 22 & 2.54 & 11.93 & & \\
\hline Ukraine & Mar 31 & 1.30 & & & \\
\hline United Arab Emirates & Apr 5 & 2.83 & & & \\
\hline United Kingdom & Mar 13 & 4.14 & 37.30 & 166.88 & \\
\hline United States & Mar 5 & 0.17 & 2.42 & 21.62 & 71.45 \\
\hline
\end{tabular}

10 since the $10^{\text {th }}$ death, 17 countries $(21.8 \%)$ presented mortality below one per million, and 19 (24.4\%) above 10 per million. Numbers were extremely high in two small areas: San Marino, with a population of 33.8 thousand inhabitants presented a mortality of 618.78 per million. In Andorra, with a population of 77.0 thousand people, mortality on day 10 since the $10^{\text {th }}$ death was 336.50 per million.

For 48 countries and territories, information on mortality on day 20 since the $10^{\text {th }}$ death was available. Only China, India, Indonesia, Japan and Pakistan had a mortality below one per million inhabitants on day 20. More than half of the countries $(54.2 \%)$ presented mortality figures on day 20 above 10 per million. The highest values were found in Europe: Luxembourg (110.23 per million), Spain (139.62 per million), Belgium (175.59 per million), and San Marino (942.90 per million).
Only 17 countries and territories achieved day 30 since the $10^{\text {th }}$ death. Four Asian countries (Japan: 0.67 per million; China:1.55 per million; South Korea: 2.71 per million; and Philippines: 3.06 per million) had the lowest mortality figures. Italy (135.04 per million), France (136.52 per million), Sweden (138.62 per million) Netherlands (164.75 per million), United Kingdom (166.88 per million), Spain (311.13 per million), Belgium (445.48 per million), and San Marino $(1,119.69)$ presented the highest mortality figures on day 30 since the $10^{\text {th }}$ death.

Although the absolute number of deaths in San Marino on April 18, $2020(\mathrm{~N}=39)$ might appear low, it represents $0.12 \%$ of its entire population. Would this catastrophic figure of $0.12 \%$ happen in other places, it would represent millions of deaths in populous countries, such as China, India, United States, Indonesia, Pakistan, Brazil, Nigeria, Bangladesh, Mexico and Japan. 
The six countries which achieved day 40 since the $10^{\text {th }}$ death showed remarkable differences in mortality (Figure 1). In both Italy and Spain, mortality was greater than 250 per million, whereas in China and South Korea, mortality was below 4 per million. Iran (41.10 per million) and the United States (71.45 per million) presented intermediate values.

In Figure 2, we compare mortality per million figures on days 10, 20 and 30 for the 16 countries with data, except San Marino. Belgium and Spain presented similar curves, but from day 20 to 30 , the difference became larger. United Kingdom and Netherlands came next, with the difference that from day 20 to 30 , the increase was much larger in the United Kingdom. Curves for the Asian countries were similar, with mortality figures much lower as compared to those observed in European countries or the United States.

Figure 3 presents ecological data on mortality on day 10 since the $10^{\text {th }}$ death and life expectancy. Spearman's correlation coefficient was $0.53(\mathrm{P}<$ $0.001)$. No correlation was found between mortality on day 10 since the $10^{\text {th }}$ death and population density (rho 0.12; $\mathrm{P}=0.31$ ).

\section{Discussion}

All analyses presented in this article refer to the number of deaths. Although some degree of un- derreporting due to insufficient testing is possible, mortality statistics are much more reliable than those on number of cases. Recent serological studies in South Brazil ${ }^{4}$ and Santa Clara, United States ${ }^{3}$, suggested that each confirmed case represents many more real cases at the population level. Recently, data from massive testing in Iceland were published ${ }^{6}$. While $13.3 \%$ of those recruited for targeted testing had positive results for infection with SARS-CoV-2, the figure in the general population was $0.8 \%$. In order to help overcome this limitation, serological surveys with population samples are urgently required. Another report showed that $86 \%$ of COVID-19 infections were undocumented, contributing to the rapid dissemination of the virus ${ }^{7}$. It is also important to keep in mind that, until reliable prevalence estimates are not available, case fatality is another statistic that should not be used at this stage, because the denominator (number of cases) is unavailable.

Two issues that are easily depicted by scientists should be widely disseminated to the public and to politicians, to avoid misinterpretation and misguided policies. First, analyzing the absolute number of deaths is misleading. For example, as of April 18, 2020, China ranks $7^{\text {th }}$ in the absolute number of deaths. However, when adjusting for its population, there are around 80 countries and territories with higher mortality rates per million, as compared to China. Second, adjusting for

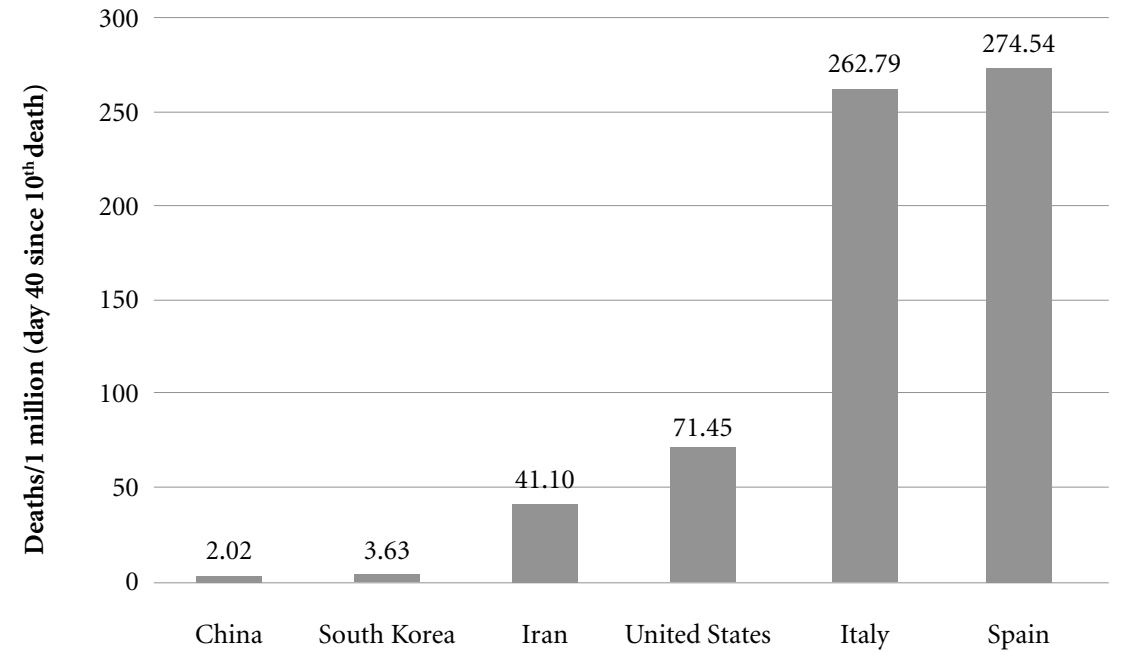

Figure 1. Mortality (deaths per one million people) on day 40 since the $10^{\text {th }}$ death. 


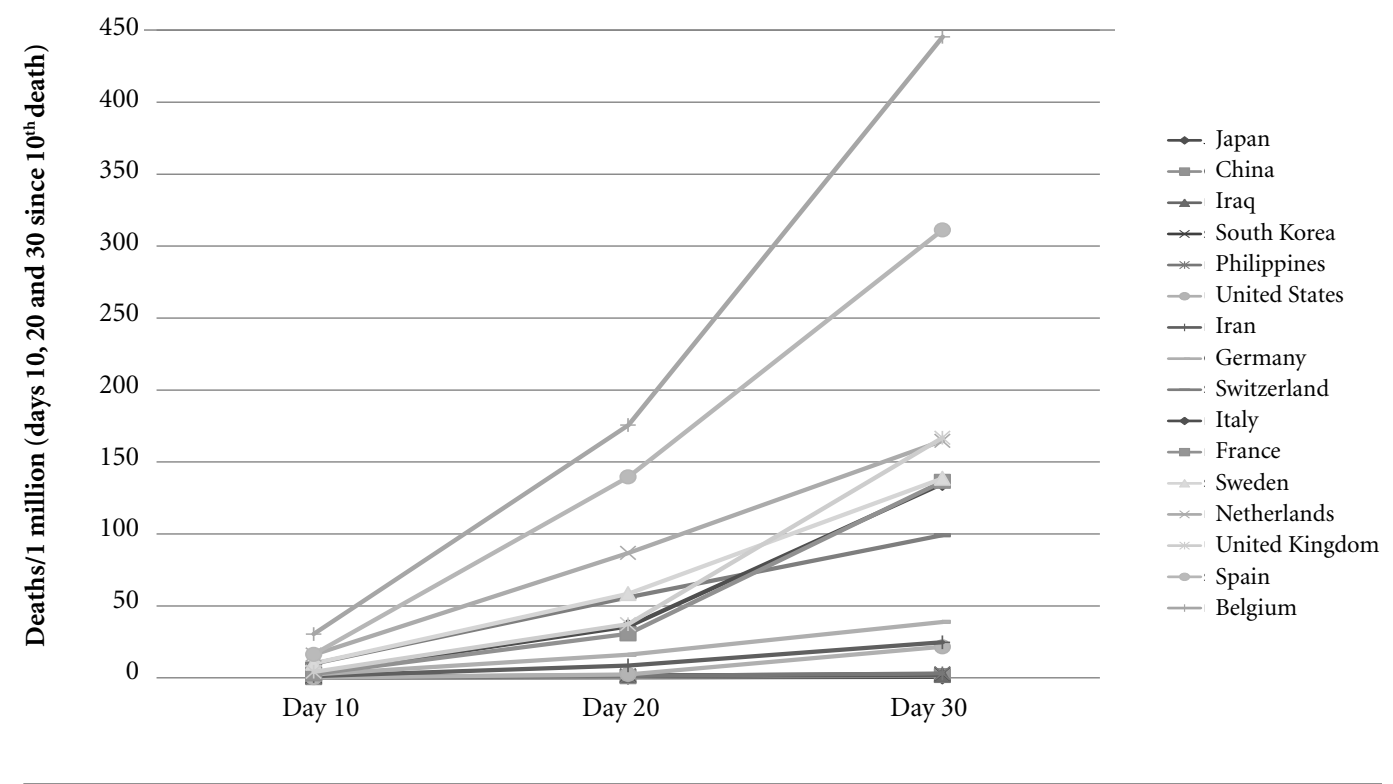

Figure 2. Mortality per million on days 10,20 and 30 since the $10^{\text {th }}$ death.

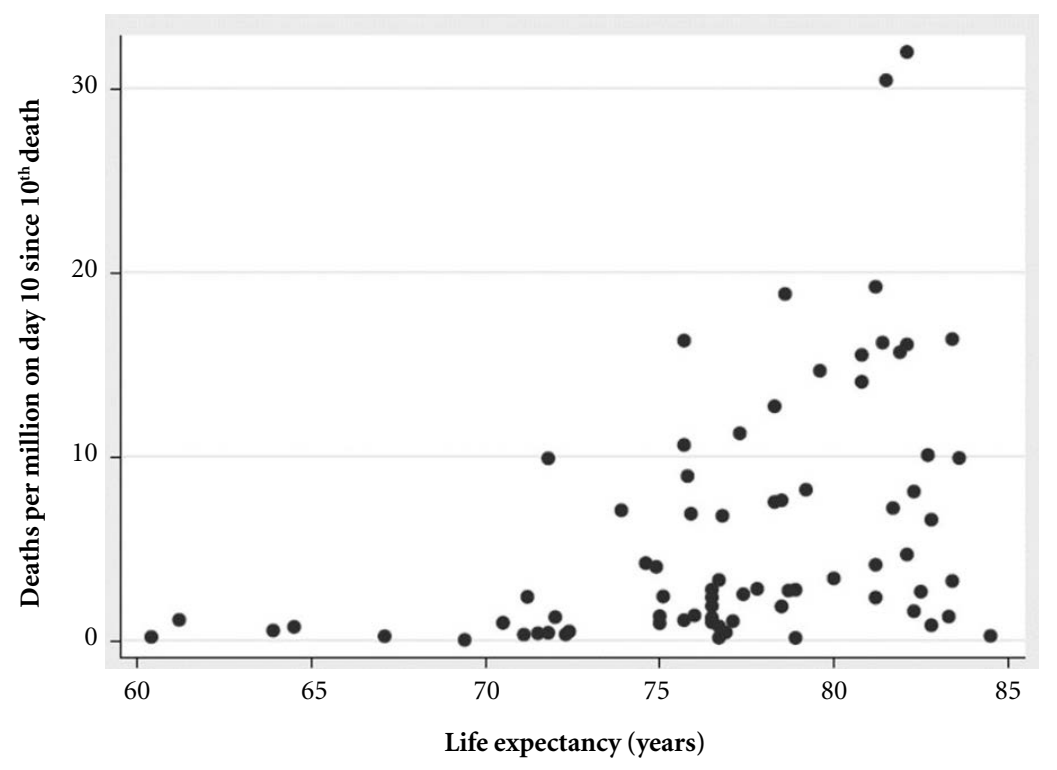

Figure 3. Scatter plot of life expectancy (years) and mortality on day 10 since the $10^{\text {th }}$ death.

the stage of the pandemic in each setting is also essential to correctly interpreting COVID-19 statistics. In this article, we opted to take the date of the $10^{\text {th }}$ death as the baseline figure. Again, ignoring this figure would lead to biased conclu- sions. For example, when comparing Italy and Spain only, mortality figures were higher in Italy than in Spain until April 5, 2020 if we ignore the stage of the pandemic in each country. However, the $10^{\text {th }}$ death in Italy took place on February 
26, whereas it happened on March 10 in Spain. When we adjust for the stage of the pandemic, figures were higher in Spain than in Italy all the time ( 10.10 vs. 3.26 per million, respectively, on day $10 ; 58.52$ vs. 35.69 per million, respectively, on day 20; and 138.62 vs. 135.04 per million, respectively, on day 30 ).

On one hand, we found life expectancy to be moderately correlated with mortality. This finding is in accordance with previous studies showing increasing fatality rates with increasing age $^{2}$. On the other hand, we found no evidence of an ecological association between mortality and population density, despite the fact that the highest mortality figures on day 10 since the 10th death were observed in two small areas (San Marino and Andorra).

In conclusion, Asian countries presented much lower mortality figures as compared to European ones. Although life expectancy was correlated with mortality, its correlation with mortality was just moderate, so that there are other factors contributing to these differences. Likely explanations are the implementation and adherence to social distancing measures, testing policies and health system structures.

\section{Acknowledgments}

To Aline E. Lamas, who helped collect the data, fill the spreadsheets and search for data. 


\section{References}

1. World Health Organization (WHO). Coronavirus disease (COVID-19) Pandemic. [cited 2020 Abr 15]. Available from: https://www.who.int/emergencies/ diseases/novel-coronavirus-2019

2. Our World in Data. Roser M, Ritchie H, Ortiz-Ospina E, Hasell J. Statistics and Research. Coronavirus Disease (COVID-19). [cited 2020 Abr 15]. Available from: https://ourworldindata.org/coronavirus

3. Bendavid E, Mulaney B, Sood N, Shah S, Ling E, Bromley-Dulfano R, Lai C, Weissberg Z, Saavedra R, Tedrow J, Tversky D, Bogan A, Kupiec T, Eichner D, Gupta R, Ioannidis J, Bhattacharya J. COVID-19 Antibody Seroprevalence in Santa Clara County, California. medRxiv 2020; 2020.04.14.20062463.

4. Hallal PC, Barros AJD, Horta BL, Dellagostin OA, Hartwig FP, Pellanda LC, Struchiner CJ, Burattini MN, Silveira MF, Menezes AMB, Barros FC, Victora CG. Population-based survey of COVID-19 in Southern Brazil. [submitted for publication]

5. Victora CG. What's the denominator? Lancet 1993; 342(8863):97-99.

6. Gudbjartsson DF, Helgason A, Jonsson H, Magnusson OT, Melsted P, Norddahl GL, Saemundsdottir J, Sigurdsson A, Sulem P, Agustsdottir AB, Eiriksdottir B, Fridriksdottir R, Gardarsdottir EE, Georgsson G, Gretarsdottir OS, Gudmundsson KR, Gunnarsdottir TR, Gylfason A, Holm H, Jensson BO, Jonasdottir A, Jonsson F, Josefsdottir KS, Kristjansson T, Magnusdottir DN, le Roux L, Sigmundsdottir G, Sveinbjornsson G, Sveinsdottir KE, Sveinsdottir M, Thorarensen EA, Thorbjornsson B, Löve A, Masson G, Jonsdottir I, Möller AD, Gudnason T, Kristinsson KG, Thorsteinsdottir U, Stefansson K. Spread of SARS-CoV-2 in the Icelandic Population. N Engl J Med 2020 ; doi: 10.1056/NEJMoa2006100. [Epub ahead of print]

7. Li R, Pei S, Chen B, Song Y, Zhang T, Yang W, Shaman J. Substantial undocumented infection facilitates the rapid dissemination of novel coronavirus (SARSCoV2). Science 2020; pii: eabb3221. [Epub ahead of print]

Article submitted 22/04/2020

Approved 23/04/2020

Final version submitted 25/04/2020 